\title{
Intrauterine fetal demise: a retrospective study in tertiary care center in India
}

\author{
Anand Karale ${ }^{1}$, Kunaal K. Shinde ${ }^{2 *}$, Hemant Damle ${ }^{1}$
}

\begin{abstract}
${ }^{1}$ Department of Obstetrics and Gynecology, Smt. Kashibai Navale Medical College and General Hospital, Narhe, Pune, Maharashtra, India

${ }^{2}$ Department of Obstetrics and Gynecology, Post Graduate Institute Yashwantrao Chavan Memorial Hospital, Pimpri, Pune, Maharashtra, India
\end{abstract}

Received: 28 June 2018

Accepted: 07 July 2018

\section{*Correspondence:}

Dr. Kunaal K. Shinde,

E-mail: dr.kunaal.shinde@gmail.com

Copyright: (c) the author(s), publisher and licensee Medip Academy. This is an open-access article distributed under the terms of the Creative Commons Attribution Non-Commercial License, which permits unrestricted non-commercial use, distribution, and reproduction in any medium, provided the original work is properly cited.

\section{ABSTRACT}

Background: An Intrauterine Fetal Demise (IUFD) is a major obstetrical catastrophe at any gestational age but the emotional pain and distress caused by this event increases in direct relation to the duration of pregnancy. The objective of the present study was to determine the incidence and possible causes of Intrauterine Fetal Demise (IUFD), and to determine preventive measures.

Methods: Retrospective observational study was done from Jan 2015 to Dec 2017 at Smt. Kashibai Navale Medical College and General Hospital, Narhe, Pune. Inclusion criteria were all the pregnant women with IUFD delivered at the centre, at or above 24 weeks of gestation. The methodology followed were parameters of assessment for analysis were maternal age, parity, probable causes for IUFD, booked or unbooked cases, mode of delivery, maternal complications, and placental histopathology. Statistical data were analyzed using SPSS version 25.

Results: The incidence of IUFD at authors' hospital was 27/1000 live births. The IUFD rate was similar in maternal age <20years and >30years ( $p$ value 0.26 ). The incidence of IUFD increased with decreasing gestational age which was statistically significant ( $p$ value 0.001). IUFD incidence was higher in multiparous women compared to primiparous women (p value 0.036 with OR of 1.6 and $95 \%$ CI 1.02 to 2.54 ). The rate of IUFD was similar when sex of the baby was analyzed. $49.4 \%$ of fetuses had signs of maceration. The major cause of IUFD was severe preeclampsia (48.1\%) which included HELLP syndrome, IUGR, Abruption. Maternal anemia (20.4\%), GDM (3.8\%), SLE (2.5\%), APLA positive (2.5\%), anhydramnios (6.3\%) were some of the other important causes of IUFD.

Conclusions: This study was conducted to determine the incidence of IUFD and associated maternal risk factors. By understanding the contributing factors, we can seek ways of avoiding recurrence of IUFD by proper antenatal care and early diagnosis of obstetric complications and its appropriate management.

Keywords: Contributing factors, IUFD, Incidence, Preeclampsia

\section{INTRODUCTION}

An Intrauterine Fetal Demise (IUFD) is a major obstetrical catastrophe at any gestational age but the emotional pain and distress caused by this event increases in direct relation to the duration of pregnancy. Lot of importance is given for maternal, neonatal and child health all over the world. There is increasing attention and investment in the field of maternal and neonatal health care but still births remain most under studied or documented. ${ }^{1}$

Intra uterine fetal death (IUFD) is defined as fetal death after 20 weeks of gestation. 2 It can be further classified 
into early or late IUFD. Early IUFD, if fetal death occurs before 24 weeks of pregnancy and late IUFD, if fetal death after 24 weeks. ${ }^{2}$

The causes of IUFD, in a large percentage of cases remain unknown, even where extensive testing and autopsy have been performed. A rarely used term to describe this is "sudden antenatal death syndrome" or SADS, a phrase coined by Cacciature and Collis in $2000 .^{3}$

Many still births occur at full term to apparently healthy mother and a post-mortem evaluation reveals a cause of death in only $40 \%$ of autopsied cases. ${ }^{4}$ It is important to investigate the cause of IUFD. If the cause of an IUFD can be identified, the family will have answers about the possibility of recurrence and can seek appropriate medical treatment to prevent recurrence. Identification of causes of IUFD will be helpful in counselling the parents as well as for formulating preventive measures. ${ }^{5}$ Health education to encourage the utilization of the available antenatal care services, family planning and genetic counselling are being advocated strongly as possible preventive measures. ${ }^{6}$ Objectives of this study were to find out the incidence and possible causes of IUFD, and to suggest preventive measures.

\section{METHODS}

Retrospective observational study was done from Jan 2015-Dec 2017 at the Smt. Kashibai Navale Medical College and General Hospital, Narhe, Pune.

All the pregnant women delivered at the hospital at or after 24 weeks of gestation with Intrauterine Fetal Demise or Fresh Still Birth, were enrolled in present study.

The parameters for the analysis included maternal age (<20 years, 20- 30 years and >30 years), parity, and probable cause for IUFD (if found on gross examination, preexisting maternal or fetal complication diagnosed during pregnancy), booked case or unbooked case, mode of delivery (vaginal /LSCS/ Laparotomy), maternal complications-early and late IUFD and placental histopathology.

"Booked Case" by definition(WHO) is when the pregnant lady has had a minimum of three visits for antenatal check-up after she was registered and confirmed to be pregnant. All others who had no prior antenatal visits would be-unbooked case".

All the details were thoroughly scrutinized and entered in a preformed proforma. The proformas were then compiled altogether and inferences were drawn.

The statistical data collected was entered in the computer using SPSS version 25. Observed differences were subjected to Chi-square test and Fischer test and incidence was calculated for 1000 live births.

\section{RESULTS}

There were a total of 11570 deliveries with 316 cases of intrauterine fetal demise (IUFD). The incidence of IUFD was $27 / 1000$ live births in present study. When maternal characteristics were studied (Table 1), 260 of the mothers were between $20-30$ years of age $(82.3 \%)$. 12 were less than 20years $(3.8 \%)$ and 44 in more than 30years $(18.9 \%)$ of age group. $94.9 \%(247 / 316)$ of the mothers had regular antenatal visits (Booked).

Majority of cases were referred from outside (80\%) after the diagnosis of IUFD for further management. Out of 316 women, 136 were primigravida $(43 \%)$ and 180 were multigravida (57\%). $93.7 \%$ of them had nonconsanguineous marriage

When gestational age was observed, 76 of the IUFDs were less than 28 weeks $(24.1 \%)$ of gestation. 136 were between 28-34 weeks (43.0\%), 64 were between 3437 weeks $(20.3 \%) .300(94.9 \%)$ had vaginal delivery and $16(5.1 \%)$ had to undergo Caesarean delivery for other obstetric indication.

Table 1: Maternal characteristics.

\begin{tabular}{|c|c|c|c|}
\hline \multicolumn{2}{|c|}{ Maternal characteristics } & Frequency & Percent \\
\hline \multirow{3}{*}{$\begin{array}{l}\text { Maternal age } \\
\text { in years }\end{array}$} & $<20$ & 12 & 3.8 \\
\hline & $20-30$ & 260 & 82.3 \\
\hline & $>30$ & 44 & 13.9 \\
\hline \multirow{2}{*}{$\begin{array}{l}\text { Antenatal } \\
\text { visits }\end{array}$} & Booked & 300 & 94.9 \\
\hline & Unbooked & 16 & 5.1 \\
\hline \multirow{2}{*}{ Parity group } & Primi & 136 & 43 \\
\hline & Multi & 180 & 57 \\
\hline \multirow{2}{*}{ Consanguinity } & Yes & 20 & 6.3 \\
\hline & No & 296 & 93.7 \\
\hline \multirow{4}{*}{$\begin{array}{l}\text { Gestational } \\
\text { age } \\
\text { in weeks }\end{array}$} & $<28$ weeks & 76 & 24.1 \\
\hline & $28-34$ & 136 & 43 \\
\hline & $34-37$ & 64 & 20.3 \\
\hline & $>37$ & 40 & 12.7 \\
\hline \multirow{2}{*}{ Baby sex } & Boy & 160 & 51.9 \\
\hline & Girl & 156 & 48.75 \\
\hline \multirow{2}{*}{$\begin{array}{l}\text { Signs of } \\
\text { maceration }\end{array}$} & Absent & 160 & 50.6 \\
\hline & Present & 156 & 49.4 \\
\hline \multirow{2}{*}{$\begin{array}{l}\text { Mode of } \\
\text { delivery }\end{array}$} & Vaginal & 300 & 94.9 \\
\hline & $\begin{array}{l}\text { Caesarean } \\
\text { delivery }\end{array}$ & 16 & 5.1 \\
\hline
\end{tabular}

When fetal parameters were studied 160 (50.6\%) were boys and 156(49.4\%) were girl babies. Out of them 156 $(49.4 \%)$ had signs of maceration and two babies had true knot in the cord. Cord around the neck was seen in $21.25 \%$ of the babies' Placental histopathology did not reveal much of the information (Table1).

When the incidence of intrauterine fetal demise was calculated per 1000 live births for the maternal age, there was no difference in the various age groups ( $\mathrm{P}$ value 0.26) (Table 2). 
Table 2: Maternal age.

\begin{tabular}{lllll}
$\begin{array}{llll}\text { Maternal } \\
\text { age in } \\
\text { years }\end{array}$ & $\begin{array}{l}\text { No. of } \\
\text { live } \\
\text { births }\end{array}$ & $\begin{array}{l}\text { No. of } \\
\text { IUFD }\end{array}$ & $\begin{array}{l}\text { IUFD per } \\
\text { 1000 live } \\
\text { birth }\end{array}$ & $\begin{array}{l}\text { P } \\
\text { value }\end{array}$ \\
\hline$<20$ & 150 & 12 & 20 & \\
\hline $20-30$ & 1947 & 260 & 33.4 & 0.26 \\
\hline $30-40$ & 554 & 44 & 19.9 & \\
\hline
\end{tabular}

P-value not statistically significant using by Fisher's exact test

Table 3: Gestational age.

\begin{tabular}{|c|c|c|c|c|}
\hline $\begin{array}{l}\text { Gestational } \\
\text { age in } \\
\text { weeks }\end{array}$ & $\begin{array}{l}\text { No. of } \\
\text { live } \\
\text { birth }\end{array}$ & $\begin{array}{l}\text { No. of } \\
\text { IUD }\end{array}$ & $\begin{array}{l}\text { IUD per } \\
1000 \text { live } \\
\text { births }\end{array}$ & $\begin{array}{l}\mathbf{P} \\
\text { value }\end{array}$ \\
\hline$<28$ & 36 & 76 & 52.8 & \multirow{4}{*}{$<0.001$} \\
\hline $28-34$ & 233 & 136 & 14.6 & \\
\hline $34-37$ & 336 & 64 & 4.7 & \\
\hline$>37$ & 2036 & 40 & 0.5 & \\
\hline
\end{tabular}

*P-value statistically significant at $5 \%$ level by using chi-square test

As the gestational age reduced, the incidence of IUFD raised, it was highest at gestation less than 28 weeks, 52.8/1000 live births. At 28-34 weeks the incidence of IUFD was 14.6/1000 live births. All these values were statistically significant (Table 3 ). There was a significant difference between parity, IUFD was observed more in multigravida compared to primigravida with odds ratio 1.6 with $95 \%$ confidence interval of 1.02 to 2.54 (Table 4).

Table 4: Comparison between parity.

\begin{tabular}{|c|c|c|c|c|c|c|}
\hline Parity & $\begin{array}{l}\text { Live } \\
\text { birth }\end{array}$ & IUD & $\begin{array}{l}\text { Total } \\
\text { births }\end{array}$ & $\begin{array}{l}\text { p- } \\
\text { value }\end{array}$ & OR & $\begin{array}{l}95 \% \\
\text { CI }\end{array}$ \\
\hline Primi & $\begin{array}{l}4876 \\
(98 \%)\end{array}$ & $\begin{array}{l}99 \\
(2 \%)\end{array}$ & 4975 & \multirow{3}{*}{$0.036^{*}$} & \multirow{3}{*}{1.6} & \multirow{3}{*}{$\begin{array}{l}1.02 \\
\text { to } \\
2.54\end{array}$} \\
\hline Multi & $\begin{array}{l}6331 \\
(96 \%)\end{array}$ & $\begin{array}{l}264 \\
(4 \%)\end{array}$ & 6595 & & & \\
\hline Total & $\begin{array}{l}11207 \\
(97 \%)\end{array}$ & $\begin{array}{l}363 \\
(3 \%)\end{array}$ & 11570 & & & \\
\hline
\end{tabular}

*P-value statistically significant at $5 \%$ level by using chi-square test

The possible associated risk factors involved in IUFD. Many of the risk factors were overlapping where causes of IUFD could not be assigned to one particular risk factor. There were $152(48.1 \%)$ cases with severe preeclampsia along with abruption, HELLP syndrome, ante partum eclampsia and severe Intrauterine growth retardation (IUGR). 64 of them (20.4\%) were anemic, out of them 20(6.3\%) had severe anemia requiring blood transfusion.

Systemic lupus erythematosus (SLE), antiphospholipid antibody syndrome (APLA) and gestational diabetes mellitus (GDM) were the next major cause of IUFD. $8(10.8 \%)$ of them had hypothyroidism on regular treatment. Miscellaneous group included cases of Cortical venous thrombosis (CVT) 4(1.3\%), Acute Fatty
Liver of Pregnancy (AFLP) $8(2.5 \%)$, thrombocytopenia, acute liver failure $4(1.3 \%)$, chronic liver disease $4(1.3 \%)$, extra hepatic portal vein obstruction 4(1.3\%), ARDS with H1N1 4(1.3\%), Twin to twin transfusion syndrome (TTTS) with one twin IUFD 4(1.3\%), bronchial asthma 4(1.3\%), Insulinoma 4(1.3\%), Seizure disorder 4(1.3\%), disseminated tuberculosis on anti-tuberculosis therapy (ATT) 1(1.3\%), polyhydramnios 1(1.3\%), Preterm Premature rupture of membrane (PPROM) 8 (2.5\%), Aplastic anemia $8(1.3 \%)$, fetal hydrops $8(1.3 \%)$, sepsis $8(1.3 \%)$, decreased fetal movement 8(1.3\%), Dichorionic diamniotic (DCDA) twin with one twin IUFD 4(1.3\%), cord and hand prolapse $4(1.3 \%)$

\section{DISCUSSION}

The incidence of IUFD reported from western countries ranges from $4.7 \%$ to $12.0 \%$ and incidence of IUFD in India, reported from various centers ranges between 24.4$41.9 \%{ }^{7-9}$ However, the incidence rate of IUFD in present study is $27 / 1000$ live births.

The incidence is higher in present study due to authors' center being a tertiary care referral hospital. Most of the cases would be referred from all over the district. $80 \%$ of the cases were referred from outside.

Unlike other studies where the majority were unbooked cases, in present study $94.9 \%$ of the cases were booked and $82.3 \%$ of them were between $20-30$ years of age. ${ }^{10}$ The incidence was higher in lesser gestational age group compared to higher gestational age and $93.7 \%$ of them had non-consanguineous marriage. In present study $43 \%$ of cases were primipara and $57 \%$ of cases were multipara, which was unlike study conducted by Singh et al where parity had no association with IUFD. ${ }^{11}$

When the risk factors were analyzed severe eclampsia was seen in $48.1 \%$ of the cases, $10.1 \%$ of these were complicated by HELLP syndrome and Ante partum eclampsia was seen in $5 \%$. Incidence of abruption was $8.9 \%$.

Chronic hypertension accounted for $3.8 \%$ of IUFD. $20.2 \%$ of pregnancies were complicated by anemia, out of them $6.3 \%$ had severe anemia needing blood transfusion. Mild anemia was seen in $2.5 \%$ and moderate anemia was seen in $11.4 \%$ of cases. SLE $(2.5 \%)$, APLA positive $(2.5 \%)$, anhydramnios $(6.3 \%)$ were the other risk factors for IUFD noted in present study. IUFD because of GDM was $3.8 \%$ in present study, which was lower when compared with the study from Iran. ${ }^{5}$ Other Indian studies showed $1.25 \%$ IUFD were because of GDM. ${ }^{1}$

$10.1 \%$ of the cases had associated hypothyroidism. No studies earlier have related hypothyroidism to IUFD. When fetal parameters were studied, $51.2 \%$ of babies were male and $48.8 \%$ were females which was almost similar to Singh et al study. ${ }^{7}$ 
Out of the 80 babies, 40 had signs of maceration, which was comparatively higher. ${ }^{7}$ None of the foetus had any anomalies. $21.25 \%$ of babies had cord around the neck. Two babies had true knot on the cord. When obstetric history was analyzed $34.17 \%$ of the cases had history of previous abortion.

Out of them $22.5 \%$ had one abortion, $8.8 \%$ had two abortions, $2.5 \%$ had three abortions previously. $10 \%$ had history of one previous IUFD and $1.3 \%$ had two previous IUFD.

In authors' center the obstetric care is divided into high risk and low risk prenatal care. In low risk group, all the pregnant women will be called once in 4 weeks till 28weeks, once in 2 weeks between 28 weeks to 37 weeks. Every visit weight gain and blood pressure is recorded, will be also provided with calcium, folic acid and oral iron supplements.

Every pregnant woman will be screened for GDM between 24 to 28 weeks. Screening for anemia is done at first visit, 32 weeks, and 36 weeks. Regular nuchal translucency scan at 13 weeks and anomaly scan is done between 20-22 weeks of gestation. After 37 weeks they are followed every week with ultrasound evaluation of amniotic fluid evaluation and Non-stress test. Beyond 40 weeks of gestation, if there are no signs of onset of labour, they will be admitted and induction of labour will be initiated.

In high risk pregnancies, more frequent visits are advised with an intense monitoring of growth of the foetus with ultrasound and Doppler. Multi department approach is offered to pregnant women with other associated systemic diseases.

Most of the causes of IUFD in present study were preventable. When a pregnant lady is detected to have pre-eclampsia, which is the most common cause in present study, she should be treated aggressively with adequate control of blood pressure and close monitoring of other parameters like fetal growth, liver, and renal function tests along with coagulation profile.

This makes it more pertinent to smaller centers in India to identify pre-eclampsia in its early stages and keep the threshold lower to refer to an appropriate center. Timely decision for delivery should be taken to avoid the associated complications in general and specifically IUFD.

Nearly one-fifth $(20.4 \%)$ of present study group had anemia, indicating that proper precautions should be taken to prevent and also treat anemia early in the pregnancy. This will avoid complications associated with anemia especially pre-eclampsia, morbidity and mortality associated with anemia and pregnancy.
To summarize the results which can have implications on preventing IUFD in India, in rural and peripheral centers where antenatal care is provided, health care personnel should be trained to identify the pregnancy as high risk or low risk.

The proper risk stratification will help to reduce the complications of high risk pregnancy including early detection of pre-eclampsia, anemia, GDM, previous pregnancy loss. This will aid timely referral to a higher center.

\section{CONCLUSION}

This study was conducted to determine the incidence of IUFD and associated maternal risk factors. By understanding the contributing factors, we can seek ways of avoiding recurrence by proper antenatal care and early diagnosis of complications and its proper management. Antenatal screening for anemia, preeclampsia, GDM, previous pregnancy loss and antenatal supervision can play an important role in decreasing the incidence of IUFD. By determining the cause of IUFD the chances of recurrence can be reduced and further pregnancy complications can be prevented.

\section{Funding: No funding sources \\ Conflict of interest: None declared}

Ethical approval: The study was approved by the Institutional Ethics Committee

\section{REFERENCES}

1. Lawn JE, Blencowe H, Pattinson R, Cousens S, Kumar R, Ibiebele I, et al. Lancet's Stillbirths Series Steering Committee. Stillbirths: Where? When? Why? How to make the data count? Lancet. 2011;377(9775):1448-63.

2. Robinson GE. Pregnancy loss. Best Pract Res Clin Obstet Gynaecol. 2014;28(1):169-78.

3. Collins JH. Umbilical cord accidents: human studies. In Semin Perinatol. 2002;26(1):79-82.

4. Cacciatore J, Radestad J, Frederik Frøen J. Effects of contact with still born babies on maternal anxiety and depression. Birth. 2008;35(4):313-20.

5. Safarzadeh A, Ghaedniajahromi M, Ghaedniajahromi M, Rigi F, Massori N. Intra uterine fetal death and some related factors: A silent tragedy in Southeastern Iran. J Pain Relief. 2014;3(129):2167-0846.

6. Archibong EI, ASobande A, Asindi AA. Antenatal intrauterine fetal death, a prospective study in a tertiary hospital in South Western Saudi Arabia. J Obstet Gynaecol. 2003;23(2):170-3.

7. Fretts RC, Boyd ME, Usher RH, Usher HA. The changing pattern of fetal death, 1961-1988. Obstetr Gynecol. 1992;79(1):35-9.

8. Malati AJ, Lalana GC. Perinatal mortality in vellore Part I: A study of 21,585 infants. Indian J Pediatr. 1986;53(3):347-52. 
9. Kumari R, Mengi V, Kumar O. Maternal risk factors and pregnancy wastage in a rural population of Jammu District. JK Science. 2013;15:82-5.

10. Sharma S, Sidhu H, Kaur S. Analytical study of intrauterine fetal death cases and associated maternal conditions. Int J Appl Basic Med Res. 2016;6(1):113.
11. Neetu S, Kiran P, Neena G, Arya AK. A retrospective study of 296 cases of intrauterine fetal death at a tertiary care center. Int $\mathbf{J}$ Reprod Contracept Obstet Gynaecol. 2013;2(2):141-6.

Cite this article as: Karale A, Shinde KK, Damle H. Intrauterine fetal demise: a retrospective study in tertiary care center in India. Int J Reprod Contracept Obstet Gynecol 2018;7:3069-73. 